\title{
PENGEMBANGAN VARIABEL-VARIABEL INDEKS KEPEKAAN EKOLOGI (IKE) BAGI PENGENDALIAN TUMPAHAN MINYAK DI EKOSISTEM MANGROVE
}

\section{DEVELOPMENT OF VARIABLES OF ECOLOGICAL SENSITIVITY INDEX (ESI) FOR OIL SPILL MANAGEMENT IN MANGROVE ECOSYSTEM}

\author{
Muarif $^{1,2^{*}}$, Ario Damar ${ }^{3,4}$, Sigid Hariyadi ${ }^{4}$, Dewayani Sutrisno ${ }^{5}$, Mennofatria Boer ${ }^{4}$ \\ 1Program Studi Pengelolaan Sumberdaya Pesisir dan Lautan Sekolah Pascasarjana Institut Pertanian Bogor \\ 2Jurusan Perikanan Universitas Djuanda Bogor \\ ${ }^{3}$ Pusat Kajian Sumberdaya Pesisir dan Lautan (PKSPL) Institut Pertanian Bogor \\ ${ }^{4}$ Fakultas Perikanan dan Ilmu Kelautan Institut Pertanian Bogor \\ ${ }^{5}$ Badan Informasi Geospasial (BIG) \\ *E-mail:muarif2010@gmail.com
}

Diterima tanggal:24 Oktober 2016, diterima setelah perbaikan:2 November 2016 disetujui tanggal 12 Januari 2017

\begin{abstract}
ABSTRAK
Ketepatan suatu indeks dalam menggambarkan kondisi lingkungan sangat ditentukan oleh ketepatan dalam memilih variabel-variabel pembentuknya. Survei pakar internasional telah dilakukan untuk menilai validitas variabel-variabel terpilih dari indeks kepekaan ekologi (IKE) ekosistem mangrove terhadap tumpahan minyak. Variabel-variabel IKE ekosistem mangrove hasil studi literatur dan telah disaring melalui survei pakar internasional adalah sebanyak 26 variabel yang meliputi tipe pasut, rentang pasut, tinggi gelombang, curah hujan, jumlah hari hujan, lama penggenangan pasang, jenis substrat, tipologi mangrove, jenis mangrove, umur flora mangrove, jumlah jenis mangrove, keberadaan flora invasif, kerapatan pohon, kerapatan anakan, kerapatan semai, perbandingan anakan dan pohon, kondisi ekosistem mangrove, jenis fauna, umur fauna, kemampuan gerak fauna, ruang hidup fauna, keberadaan flora mangrove dilindungi, keberadan fauna dilindungi, keberadaan nurshery habitat, keberadaan spawning ground, dan status lindung ekosistem mangrove. Variabel-variabel tersebut mampu mewakili 6 karakteristik ekosistem mangrove. Variabel-variabel yang memiliki rangking yang tertinggi adalah variabel keberadaan nurshery habitat, sedangkan variabel yang memiliki rangking terendah adalah keberadaan flora invasif. Variabel-variabel IKE ekosistem mangrove telah diujicoba di Pesisir Kabupaten Indramayu, dan mendapatkan sebaran IKE ekosistem mangrove tergolong mulai cukup peka sampai peka, dengan sebagian besar tergolong peka.
\end{abstract}

Kata kunci: indeks kepekaan ekologi (IKE), ekosistem mangrove, tumpahan minyak

\section{ABSTRACT}

Validity of index to describe the environmental conditions is much determined by the accuracy in selecting formulating variables. The International expert survey was used to assess the validity of selected variables of ecological sensitivity index (ESI) of mangrove ecosystems to oil spill. $t$ Identified ESI variables from literature study and assessed through expert survey were 26 variables, including tidal type, tidal range, wave height, rainfall, number of rain day, type of substrate, long time water logging, species of mangrove flora, number of mangrove flora species, condition of mangrove ecosystems, age of mangrove flora, density of mangrove trees, density of mangrove saplings, density of mangrove seedlings, density ratio of sapling and mangrove trees, presence of protected mangrove flora, kind of mangrove fauna, position of mangrove fauna, motion ability of mangrove fauna, age of mangrove fauna, presence of a protected mangrove fauna, existence of nursery habitat, existence of spawning ground, typology of mangrove, presence of invasive flora, and protection status of mangrove ecosystems. The variables were represented of 6 characteristics of mangrove ecosystem. The highest and the lowest ranking of variables were the existence of nursery habitat and presence of invasive flora respectively. Variables of Mangrove ESI were applied in Indramayu Resort, and came up with the result that the distribution of mangrove ESI in Indramayu Resort were categorized from moderate to sensitive, with dominant mangrove ESI catagorised as sensitive.

Keywords: ecological sensitivity index (ESI), mangrove ecosystem, oilspill

Pengembangan Variabel-Variabel Indeks Kepekaan Ekologi (IKE) Bagi Pengendalian Tumpahan Minyak Di Ekosistem Mangrove - Muarif, Ario, Damar, Sigid Hariyadi, Dewayani Sutrisno, Mennofatria Boer 


\section{PENDAHULUAN}

Tumpahan minyak dapat menimbulkan dampak pencemaran yang serius terhadap lingkungan pesisir, baik lingkungan perairan maupun daratan. Diantara beragam ekosistem pesisir, mangrove merupakan ekosistem pesisir yang sangat peka apabila terkena tumpahan minyak (Sloan 1993; Kankara dan Subramanian, 2007). Minyak akan terjebak di sela-sela mangrove sehingga upaya membersihkannya sangat sulit. Tumpahan minyak yang memasuki ekosistem mangrove dapat menyebabkan ekosistem mangrove mengalami gangguan. Gangguan tersebut dapat berupa kematian flora dan fauna dalam jumlah besar, atau kerusakan kecil pada ekosistem mangrove. Pencemaran minyak dapat menyebabkan kematian mangrove dan biota perairan di dalamnya serta kerusakan habitat beserta segenap fungsi ekologis dan sistem penunjang kehidupan yang ada di kawasan mangrove (Duke dan Pinzon, 1986; Taylor, 1991; Garrity et al., 1994; Soemodihardjo dan Soeroyo, 1994). Besar atau kecilnya dampak negatif yang ditimbulkan oleh tumpahan minyak menggambarkan karakteristik kepekaan ekosistem mangrove terhadap tumpahan minyak.

Sifat peka atau tidak peka ekosistem mangrove terhadap tumpahan minyak dapat diukur dalam sebuah indeks. Indeks kepekaan Ekologi (IKE) ekosistem mangrove terhadap tumpahan minyak adalah sebuah pendekatan yang betujuan untuk mengetahui gambaran respon ekosistem mangrove secara ekologis terhadap tumpahan minyak. Respon tersebut dapat bersifat sangat peka, peka, cukup peka, kurang peka, atau bahkan tidak peka terhadap tumpahan minyak. Indeks kepekaan ekologi (IKE) berguna dalam pengendalian pencemaran minyak, yaitu melalui pendeteksian wilayah yang akan terkena pengaruh buruk tumpahan minyak dan wilayah yang dapat diproteksi dari pencemaran minyak (NOOA, 2001).

Nilai indeks kepekaan ekologi (IKE) harus mampu mewakili dan menggambarkan dengan benar kepekaan ekologi mangrove di suatu area terhadap tumpahan minyak. Ketepatan suatu indeks dalam menggambarkan kondisi lingkungan sangat ditentukan oleh ketepatan dalam memilih variabel-variabel pembentuknya. Variabel-variabel yang relevan akan memberikan jaminan ketepatan dalam menilai kepekaan ekologi mangrove. Basis yang harus diperhatikan dalam penentuan variabel IKE ekosistem mangrove adalah variabel memiliki kriteria sesuai kaidah-kaidah variabel pembentuk indeks yang baik.

Salah satu kriteria variabel indeks yang baik adalah variabel harus bersifat obyektif (Hilty dan Merenlender, 2000). Suatu Variabel IKE ekosistem mangrove disebut bersifat obyektif apabila variabel tersebut dipilih karena memiliki alasan yang kuat, sehingga relevan sebagai variabel kepekaan ekologi mangrove. Relevansi tersebut dapat dilihat dari keterkaitan variabel tersebut dengan kepekaan mangrove terhadap tumpahan minyak. Hal ini berarti penentuan variabel harus didukung oleh alasan ilmiah yang kuat (Donnelly et al., 2007). Kajian mendalam untuk mendapatkan alasan ilmiah yang kuat terhadap hubungan variabel dengan kepekaan ekologi mangrove terhadap tumpahan minyak dapat dilakukan melalui metode studi literatur dan survei pakar.

Penelitian ini bertujuan untuk mendapatkan variabel-variabel IKE ekosistem mangrove yang baik. Tujuan lain yang ingin dicapai dari penelitian ini adalah mengetahui sebaran IKE ekosistem mangrove sebagai ujicoba variabel di pesisir Kabupaten Indramayu.

\section{BAHAN DAN METODE}

Penelitian ini dilaksanakan pada September 2015 - Mei 2016. Pengunpulan data dalam penelitian ini meliputi studi literatur, survei pakar, dan survei ekologi mangrove. Studi literatur dilakukan melalui kajian literaturliteratur ilmiah, baik buku laporan penelitian maupun jurnal ilmiah. Survei pakar dilakukan melalui komunikasi langsung untuk pakar nasional dan melalui email untuk para pakar dari luar negeri. Alat yang digunakan untuk survei pakar adalah kuisioner. Survei ekologi mangrove dilakukan melalui survei lapangan di Karangsong, Pabean Udik, dan Pabean Ilir Kabupaten Indramayu.

Para pakar yang berpartisipasi dalam penelitian ini sebanyak 10 orang terdiri atas 5 orang 
Profesor dan 5 orang Doktor yang berasal dari 7 negara yaitu Indonesia, Amerika Serikat, Australia, New Zealand, India, Sri Langka, dan Brazil. Pakar pakar tersebut memiliki disiplin ilmu di bidang mangrove, ekosistem pesisir, pencemaran, biologi laut, dan pengelolaan sumberdaya pesisir.

Survei lapangan dilakukan untuk mendapatkan data primer terkait dengan data ekologi mangrove. Survei dilakukan pada 6 stasiun, yaitu stasiun 1 dan stasiun 2 berada di Karangsong, stasiun 3 berada di Pabean Udik, serta stasiun 4, stasiun 5, dan stasiun 6 berada di Pabean Ilir (Gambar 1). Data ekologi yang dikumpulkan meliputi data jenis substrat, lama penggenangan air, jenis flora mangrove, jumlah jenis flora mangrove, kerapatan pohon, kerapatan anakan, kerapatan semai, keberadaan fauna dilindungi, keberadaan fauna invasif, jenis fauna, ruang hidup fauna, kemampuan gerak fauna, status lindung fauna, dan status lindung mangrove. Data lain yang dikumpulkan meliputi curah hujan, jumlah hari hujan, tipe pasang surut, rentang pasang surut, dan tinggi gelombang yang diperoleh melaui data sekunder. Data sekunder diperoleh melalui Dinas Kelautan dan Perikanan Kabupaten Indramayu, Badan Pusat Statistik Indramayu, dan Badan Meterologi, Klimatologi, dan Geofisika.

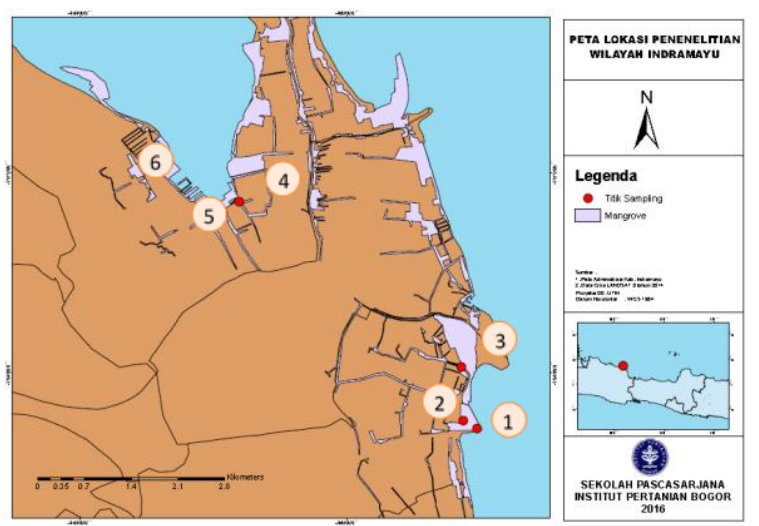

Gambar 1. Lokasi penelitian di pesisir Kabupaten Indramayu.

Figure 1. The study area in Coatal of Indramayu Resort.

Pengolahan data hasil survei pakar berupa pengolahan data secara statistika deskriptif. Data diolah untuk mendapatkan persentase persetujuan para pakar terhadap variabel yang ditawarkan peneliti dan rangking kepekaan dari setiap variabel. Analisis data dilakukan dengan mengkatagorikan variabel disetujui atau tidak oleh pakar. Variabel dikatagorikan disetujui oleh pakar apabila mendapat respon lebih besar dari $50 \%$ pakar yang berpartisipasi.

Pengolahan data ekologi mangrove yang dilakukan berupa tabulasi data, dan penghitungan kerapatan dan indeks nilai penting mangrove. Tabulasi data dibuat untuk menggambarkan karakteristik ekologi mangrove di setiap stasiun. Penghitungan nilai kerapatan dan indeks nilai penting mangrove dilakukan menggunakan microsoft excel.

Analisis tingkat kepekaan setiap variabel dilakukan melalui kriteria-kriteria tingkat kepekaan yang diperoleh melalui studi literatur (Tabel 1). Indeks kepekaan ekologi (IKE) eksistem mangrove dianalisis menggunakan formula IKE ekosistem mangrove. Nilai indeks kepekaan ekologi diperoleh melalui pembentukan formula yang berupa penjumlahan hasil kali variabel dengan bobotnya. Bobot ditentukan melalui perbandingan nilai rangking variabel dengan total nilai rangking, yang diperoleh melalui survei pakar.

$$
I K E_{e m}=\sum w_{i} X_{i}
$$

$\mathrm{IKE}_{\mathrm{em}}$ : indeks kepekaan ekologi (IKE) ekosistem mangrove

Wi : bobot variabel ke i

$\mathrm{Xi}$ : Variabel ke i

\begin{tabular}{|c|c|}
\hline Kriteria & Sanoat Peka. IKF $>4$ \\
\hline & Sangat Река: IKE>4 \\
\hline & Река $\quad: 3<1 K E \leq 4$ \\
\hline & Cukup Peka: $2<\mathrm{IKE} \leq 3$ \\
\hline & Peka $\quad: 1<\mathrm{IKE} \leq 2$ \\
\hline & Peka \\
\hline
\end{tabular}


Tabel 1. Variabel-variabel IKE ekosistem mangrove dan tingkat kepekaannya Table1. Variables of mangrove ESI and sensitivity levels

\begin{tabular}{|c|c|c|c|c|c|c|c|}
\hline \multirow{2}{*}{ No } & \multirow{2}{*}{ Variabel } & \multicolumn{5}{|c|}{ Tingkat kepekaan } & \multirow{2}{*}{ Pustaka } \\
\hline & & Tidak Peka (1) & Kurang Peka (2) & Cukup Peka (3) & Peka (4) & Sangat Peka (5) & \\
\hline 1 & Tipe pasut & & Ganda & $\begin{array}{c}\text { Campuran condong } \\
\text { ganda }\end{array}$ & $\begin{array}{c}\text { Campuran } \\
\text { Condong } \\
\text { tunggal }\end{array}$ & Tunggal & Wyrkti (1961) \\
\hline 2 & Rentang pasut & $>6$ & $4,1-6$ & $2-4$ & $1-1,9$ & $<1$ & Gibb et al. (1992) \\
\hline 3 & Tinggi gelombang & $\geq 7$ & $6-6.9$ & $5-5,9$ & $3-4,9$ & $<3$ & Gibb et al. (1992) \\
\hline 4 & Curah hujan & $>400 \mathrm{~mm} /$ bulan & $301-400 \mathrm{~mm} / \mathrm{bulan}$ & 201-300 mm/bulan & $\begin{array}{c}\text { 101-200 } \\
\mathrm{mm} / \text { bulan }\end{array}$ & $<101 \mathrm{~mm} / \mathrm{bulan}$ & BMKG (2013) \\
\hline 5 & Hari hujan & $>270$ hari & $210-270$ hari & $150-210$ hari & $90-150$ hari & $<90$ hari & Oldeman (1975) \\
\hline 6 & Jenis substrat & Berbatu /berkerikil & Pasir berkerikil & Pasir & $\begin{array}{l}\text { Lumpur } \\
\text { berpasir }\end{array}$ & Lumpur & Sloan 1993 \\
\hline 7 & $\begin{array}{l}\text { Lama waktu } \\
\text { penggenangan air } \\
\text { pasang }\end{array}$ & 1 hari/bulan & 2-9 hari/bulan & 10-15 hari/bulan & $\begin{array}{c}15-20 \\
\text { hari/bulan }\end{array}$ & $>20$ hari/bulan & Van Lonn et al (2007) \\
\hline 8 & Jenis mangrove & $\begin{array}{l}\text { Acanthus, Nypa, } \\
\text { Inocarpus, } \\
\text { Acrostichum }\end{array}$ & $\begin{array}{c}\text { Acanthus, Hibiscus, } \\
\text { Ficus, Thespesia, Merope, } \\
\text { Inocarpus, Pandanus }\end{array}$ & $\begin{array}{c}\text { Bruguiera, Ceriops, } \\
\text { Xylocarpus, } \\
\text { Heritera }\end{array}$ & Rhizophora & $\begin{array}{l}\text { Avicennia, } \\
\text { Sonneratia }\end{array}$ & $\begin{array}{l}\text { Emerson (1983), } \\
\text { Duke and Burn } \\
(1999)\end{array}$ \\
\hline 9 & $\begin{array}{l}\text { Jumlah jenis } \\
\text { mangrove }\end{array}$ & 1 & 2 & 3 & 4 & 5 & Suharnoto (2000) \\
\hline 10 & Umur mangrove & - & Pohon & $\begin{array}{l}\text { Campuran (Pohon, } \\
\text { anakan, semai) }\end{array}$ & Anakan & $\begin{array}{c}\text { Semai atau } \\
\text { campuran anakan } \\
\text { dan semai }\end{array}$ & Proffitt, 1996 \\
\hline 11 & $\begin{array}{l}\text { Kerapatan pohon } \\
\text { mangrove }\end{array}$ & $\begin{array}{c}<600 \\
\mathrm{idv} / \mathrm{Ha}\end{array}$ & $\begin{array}{l}600-900 \\
\mathrm{idv} / \mathrm{Ha}\end{array}$ & $900-1.200 \mathrm{idv} / \mathrm{Ha}$ & $\begin{array}{c}1.200-1.500 \\
\mathrm{idv} / \mathrm{Ha}\end{array}$ & $\begin{array}{l}>1.500 \\
\mathrm{idv} / \mathrm{Ha}\end{array}$ & $\begin{array}{l}\text { KepMen LH No. } 201 \\
\text { tahun } 2004\end{array}$ \\
\hline 12 & $\begin{array}{l}\text { Kerapatan anakan } \\
\text { mangrove }\end{array}$ & $<1.000$ & $1.000-<1.500$ & $1.500-<2.000$ & $2.000-<2.500$ & $\geq 2.500$ & Dephut (2005) \\
\hline 13 & $\begin{array}{l}\text { Kerapatan semai } \\
\text { mangrove }\end{array}$ & $<2.000$ & $2.000-<3.000$ & $3.000-<4.000$ & $4.000-<5.000$ & $\geq 5.000$ & Dephut (2005) \\
\hline 14 & $\begin{array}{l}\text { Perbandingan } \\
\text { kerapatan anakan \& } \\
\text { pohon }\end{array}$ & $<1,5$ & $1,5-<2,5$ & $2,5-<3,5$ & $3,5-<4,5$ & $\geq 4,5$ & $\begin{array}{l}\text { Modifikasi Dephut } \\
\text { (2005) }\end{array}$ \\
\hline 15 & Tipologi mangrove & Mangrove daratan & & $\begin{array}{l}\text { Mangrove tepi } \\
\text { bagian luar }\end{array}$ & $\begin{array}{c}\text { Mangrove } \\
\text { tepian sungai }\end{array}$ & $\begin{array}{l}\text { Mangrove tepi } \\
\text { bagian dalam }\end{array}$ & Hoff et al. (2002) \\
\hline 16 & $\begin{array}{l}\text { Kondisi ekosistem } \\
\text { mangrove }\end{array}$ & Sangat rusak & Rusak & Sedang & Baik & Sangat baik & $\begin{array}{l}\text { Modifikasi Men LH } \\
\text { (2004) }\end{array}$ \\
\hline 17 & $\begin{array}{l}\text { Keberadaan flora } \\
\text { mangrove yang } \\
\text { dilindungi }\end{array}$ & Tidak ada & & & & Ada & NOAA (2002) \\
\hline 18 & $\begin{array}{l}\text { Keberadaan flora } \\
\text { invasif }\end{array}$ & Tidak ada & & & & Ada & $\begin{array}{l}\text { Ministry of Water, } \\
\text { Land and Air } \\
\text { Protection (2004) } \\
\text { IPIECA (1993) }\end{array}$ \\
\hline 19 & Jenis fauna mangrove & Tidak ada & Fauna teresterial & Campuran & & Fauna perairan & $\begin{array}{l}\text { O'Sullivan dan } \\
\text { Jacques, (2001). }\end{array}$ \\
\hline 20 & $\begin{array}{l}\text { Ruang hidup fauna } \\
\text { mangrove }\end{array}$ & Tajuk & Batang & Akar & Perairan & Substrat & $\begin{array}{l}\text { Duke, Burn (1999) } \\
\text { Melville et al (2009) }\end{array}$ \\
\hline 21 & $\begin{array}{l}\text { Kemampuan gerak } \\
\text { fauna mangrove }\end{array}$ & Infauna & Bivalva & Gastropoda & $\begin{array}{c}\text { Kepiting, Ikan, } \\
\text { Udang }\end{array}$ & Fauna tersterial & $\begin{array}{l}\text { Duke, Burn (1999), } \\
\text { Fingas (2001) } \\
\text { Sinderman (2006) }\end{array}$ \\
\hline 22 & Umur fauna mangrove & - Dewasa & & Campuran & & Larva/anakan & Fingas (2001) \\
\hline 23 & $\begin{array}{l}\text { Keberadaan fauna } \\
\text { mangrove yang } \\
\text { dilindungi }\end{array}$ & Tidak ada & & & & Ada & NOAA (2002) \\
\hline 24 & $\begin{array}{l}\text { Keberadaan nurshery } \\
\text { habitat }\end{array}$ & Tidak ada & & & & Ada & Peters et al. (1997) \\
\hline 25 & $\begin{array}{l}\text { Keberadaan spawning } \\
\text { ground }\end{array}$ & Tidak ada & & & & Ada & Peters et al. (1997) \\
\hline 26 & $\begin{array}{l}\text { Status perlindungan } \\
\text { ekosistem mangrove }\end{array}$ & Tidak ada & & Lokal & Nasional & Internasional & IPIECA (2012) \\
\hline
\end{tabular}




\section{HASIL DAN PEMBAHASAN}

\section{Pengembangan Variabel IKE Ekosistem Mangrove \\ Variabel-variabel IKE Ekosistem Mangrove}

Variabel-variabel IKE Ekosistem Mangrove dibutuhkan untuk membentuk indeks kepekaan ekologi (IKE) ekosistem mangrove terhadap tumpahan minyak. Variabel-variabel tersebut secara ilmiah harus dapat mewakili karakteristik ekosistem mangrove dan mampu mencerminkan dampak tumpahan minyak di dalam ekosistem mangrove. Pemilihan variabel dilakukan melalui studi mendalam terhadap 23 buah literatur yang terkait dengan hasil-hasil penelitian tumpahan minyak di kawasan mangrove. Studi literatur dimaksudkan untuk memperoleh variabel yang secara ilmiah dapat dipertanggungjawabkan kebenarannya. Validitas variabel secara ilmiah adalah penting, karena itu Donnelly et al. (2007) mempersyaratkan variabel-variabel pembentuk indeks harus dinyatakan valid secara ilmiah. Hasil studi litertur diperoleh 26 variabel yang dipilih sebagai variabelvariabel indeks kepekaan ekologi (IKE) ekosistem mangrove terhadap tumpahan minyak (Tabel 2).

Tabel 2. Variabel-Variabel IKE ekosistem mangrove terhadap Tumpahan Minyak

Table2. Variables of mangrove ecosistems ESI to oil spills

\begin{tabular}{|c|c|c|}
\hline No & Variabel & Sumber litertur \\
\hline 1 & Tipe pasang surut & Brown (2007), Burnsa et al. (1999), Petersen et al. (2002) \\
\hline 2 & Rentang pasang surut & Peters et al. (1997), O'Sullivan Jacques (2001) \\
\hline 3 & Tinggi gelombang & Petersen et al. (2002), Oyedepo and Adeofun (2011) \\
\hline 4 & Curah hujan & 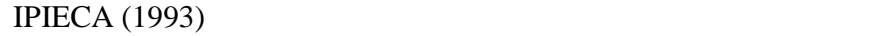 \\
\hline 5 & Jumlah hari hujan & IPIECA (1993) \\
\hline 6 & Jenis substrat & Ali dkk (2008) \\
\hline 7 & Lama waktu penggenangan air & Petersen (2002) \\
\hline 8 & Tipologi ekosistem mangrove & IPIECA, (1993). \\
\hline 9 & Jenis flora mangrove & Duke dan Burn (1999) \\
\hline 10 & Jumlah jenis flora mangrove & Faperikan IPB (1995) \\
\hline 11 & Kondisi ekosistem mangrove & Garity et al. (1994) \\
\hline 12 & Umur flora mangrove & Lin and Mendelsson (1998), Clark (1986), Hoff et al. (2002) \\
\hline 13 & Kerapatan pohon mangrove & Peterson et al. (2002), Souza et al. (2009) \\
\hline 14 & Kerapatan anakan mangrove & Lin dan Mendelsson (1998), Clark (1986), Hoff et al. (2002) \\
\hline 15 & Kerapatan semai mangrove & Lin dan Mendelsson (1998), Clark (1986), Hoff et al. (2002) \\
\hline 16 & $\begin{array}{l}\text { Perbandingan kerapatan anakan dan } \\
\text { pohon mangrove }\end{array}$ & Lin dan Mendelsson (1998), Clark (1986), Hoff et al. (2002) \\
\hline 17 & $\begin{array}{l}\text { Keberadaan flora mangrove yang } \\
\text { dilindungi }\end{array}$ & Messmer et al. (1998) \\
\hline 18 & Keberadaan flora invansif & Ministry of Water, Land and Air Protection (2004) \\
\hline 19 & Jenis Fauna mangrove & Fingas (2001), Kolyuchkina et al. (2012), Duke dan Burn (1999) \\
\hline 20 & $\begin{array}{l}\text { Ruang hidup fauna di dalam } \\
\text { ekosistem mangrove }\end{array}$ & Duke danBurn (1999), Culbertson et al. (2007), Melville et al. (2009) \\
\hline 21 & Kemampuan gerak fauna mangrove & Duke dan Burn (1999), Fingas (2001), Sindermann (2006) \\
\hline 22 & Umur fauna mangrove & Fingas (2001) \\
\hline 23 & Keberadaan fauna dilindungi & Messmer et al. (1998) \\
\hline 24 & Keberadaan nurshery habitat & Peters et al. (1997) \\
\hline 25 & Keberadaan spawning ground & Peters et al. (1997) \\
\hline 26 & $\begin{array}{l}\text { Status perlindungan ekosistem } \\
\text { mangrove }\end{array}$ & IPIECA (2012) \\
\hline
\end{tabular}

Pengembangan Variabel-Variabel Indeks Kepekaan Ekologi (IKE) Bagi Pengendalian Tumpahan Minyak Di Ekosistem Mangrove - Muarif, Ario, Damar, Sigid Hariyadi, Dewayani Sutrisno, Mennofatria Boer 


\section{Seleksi Variabel Melalui Survei Pakar}

Survei pakar adalah survei dan mengumpulkan pendapat dari para pakar tentang topik tertentu (Yousuf, 2007). Survei pakar telah banyak digunakan dalam berbagai bidang seperti akunting, teknik, kesehatan, ekologi dan lain-lain (McBride et al., 2012). Penelitian ini mengaplikasikan survei pakar dalam bidang ekologi untuk memperoleh variabel-variabel indeks kepekaan ekologi (IKE) ekosistem mangrove terhadap tumpahan minyak.

Peranan survei pakar sangat penting untuk memvalidasi variabel-variabel yang diusulkan sebagai variabel indeks kepekaan ekologi (IKE) ekosistem mangrove. Menurut CloquellBallester et al. dalam Donnelly et al. (2007) menyebutkan variabel indeks yang menjadi indikator harus divalidasi dan diterima oleh partisipan. Partisipan yang dipilih dalam penelitian ini adalah pakar, dengan tujuan untuk memperoleh kepastian kebenaran ilmiah dari setiap variabel.

Berdasarkan pertimbangan tersebut variabelvaribel indeks kepekaan ekologi (IKE) ekosistem mangrove perlu diseleksi melalui pendapat pakar. Tujuannya adalah agar variabel akhir yang diperoleh mendapat pengakuan pakar, sehingga secara ilmiah variabel-variabel tersebut diakui valid. Validitas variabel secara ilmiah adalah penting, Donnelly et al. (2007) mempersyaratkan variabel-variabel pembentuk indeks harus dinyatakan valid secara ilmiah.

Pakar adalah seseorang yang memiliki pengetahuan tentang masalah pada tingkat yang sesuai dan detail serta mampu mengkomunikasikan pengetahuan mereka (Meyer dan Booker, 2001). Pakar adalah seorang ahli yang memiliki pengetahuan yang mendalam terkait subyek yang tengah dibahas (O'Hagan et al., 2006). Pakar juga memiliki tingkat relevansi dan kedalaman pengalaman dalam kaitannya dengan topik yang dikaji (Fazey et al., 2006). Kemampuan pakar didasarkan pada pengetahuan dan pengalaman yang banyak pada tugas-tugas yang relevan dengan umpan balik berkualitas tinggi (Ericsson, 2004). Penelitian ilmiah adalah suatu bentuk tertentu dari pengalaman (Fazey et al., 2006). Para pakar sesuai kedalaman pengetahuannya dan keluasan pengalamannya akan mampu menganalisis setiap variabel dengan baik.

Faktor penting dalam tahap penelitian ini adalah menjaring partisipasi pakar. Menurut Crance (1987) dalam survei pakar tidak ada batasan yang pasti terkait jumlah pakar yang berpartisipasi. Cooke dan Goossens (2000) dalam penelitiannya hanya menggunakan partisipasi 4-8 pakar, sedangkan Clayton (1997) berpendapat 5 to10 ahli mencukupi untuk suatu penelitian survei pakar. Dengan demikian yang paling penting dalam survei pakar adalah menjaring partisipasi pakar yang memiliki keahlian sesuai bidang penilitian.

Penelitian ini menjaring partisipasi 10 orang pakar internasional yaitu terdiri atas 5 orang guru besar dan 5 orang doktor. Bidang keahlian para pakar meliputi biologi dan ekologi mangrove, biologi laut, pengelolaan sumberdaya pesisir dan lautan, oseanografi dan lingkungan (oil spill). Sebaran pakar berdasarkan institusinya adalah FPIK IPB, Fahutan IPB, Texas A \& M University, Universidade Federal Fluminense (UFF) Brazil, James Cook University, Australia, University of Auckland, New Zealand, Annamalai University, India, The Integrated Coastal and Marine Area Management Project Directorate (ICMAM-PD), India, dan University of Ruhuna, Sri Langka. Jumlah pakar yang mencukupi dan kualitas pakar yang memiliki keilmuan dan pengalaman yang baik serta sesuai dengan bidang penelitian ini, menjadi dasar yang menentukan keakuratan penelitian ini.

Tujuan pertama dari survei pakar adalah untuk mengetahui tingkat persetujuan pakar terhadap variabel-variabel indeks kepekaan ekologi (IKE) ekoosistem mangrove yang telah dipilih sebelumnya. Persetujuan pakar berperan penting untuk memvalidasi variabel (CloquellBallester et al. dalam Donnelly et al., 2007). Hasil survei pakar menunjukkan bahwa seluruh variabel disetujui oleh sebagian besar pakar, dengan persentase $80-100 \%$. Dengan demikian 26 variabel tersebut merupakan variabel yang tepat dipilih sebagai variabel indeks kepekaan ekologi (IKE) ekosistem mangrove terhadap tumpahan minyak karena selain dipilih berbasis literatur ilmiah, juga mendapat persetujuan pakar internasional. 
Tabel 3. Persentase persetujuan pakar terhadap variabel IKE ekosisistem mangrove Table 3. Percent of expert agreement to variables of mangrove ecosistems ESI

\begin{tabular}{clc}
\hline NO & \multicolumn{1}{c}{ Variabel } & PPS \\
\hline 1 & Tipe Pasang surut (TPS) & $100 \%$ \\
2 & Tinggi Gelombang (TGl) & $100 \%$ \\
& & \\
3 & Curah hujan (CHj) & $100 \%$ \\
4 & Jumlah hari hujan (JHH) & $100 \%$ \\
5 & Lama waktu penggenangan air pasang & $100 \%$ \\
& (LPP) & $100 \%$ \\
7 & Jumlah jenis mangrove (JJM) & $100 \%$ \\
8 & Kmur flora mangrove (UMg) & $100 \%$ \\
9 & Kerapatan pohon mangrove (KPM) & $100 \%$ \\
10 & Kerapatan semai mangrove (KSM) & $100 \%$ \\
11 & Tipologi mangrove (TMg) & $100 \%$ \\
12 & Keberadaan flora mangrove yang & $100 \%$ \\
& dilindungi (KML) & $100 \%$ \\
\hline PPS: Persentase pakar yang setuju & Keberadaan flora invasif (KFI) &
\end{tabular}

Hasil survei pakar tersebut disajikan secara detail dalam Tabel 3.

Variabel yang disetujui oleh seluruh pakar (100\%) adalah sebanyak 17 variabel. Tujuh belas variabel tersebut meliputi tipe pasang surut, tinggi gelombang, curah hujan, jumlah hari hujan, lama waktu penggenangan air pasang, jumlah jenis flora mangrove, umur flora mangrove, kerapatan pohon mangrove, kerapatan anakan mangrove, kerapatan semai mangrove, tipologi mangrove, keberadaan flora mangrove yang dilindungi, keberadaan flora invasif, umur fauna mangrove, keberadaan fauna mangrove yang dilindungi, keberadaan nurshery habitat, dan keberadaan spawning ground. Sebanyak 8 variabel disetujui oleh $90 \%$ pakar, hal ini juga menunjukkan pengakuannya yang tinggi pakar terhadap variabel tersebut. Delapan variabel tersebut adalah rentang pasang surut, jenis substrat, jenis flora mangrove, perbandingan kerapatan anakan dan pohon mangrove, jenis fauna mangrove, ruang hidup fauna mangrove, kemampuan gerak fauna mangrove, dan status perlindungan ekosistem mangrove. Variabel kondisi ekosistem mangrove mendapat persetujuan dari $80 \%$ responden, yang juga masih tergolong jumlah persentase yang tinggi. Keberadaan pengakuan (persetujuan) dari para pakar internasional terhadap variabel dengan tingkat persetujuan (persentase) yang tinggi memperkuat validitas variabel-variabel IKE ekosistem mangrove terpilih.

\begin{tabular}{|c|c|c|}
\hline NO & Variabel & PPS \\
\hline 14 & Umur fauna mangrove (UFM) & $100 \%$ \\
\hline 15 & $\begin{array}{l}\text { Keberadaan fauna mangrove yang } \\
\text { dilindungi (KFL) }\end{array}$ & $100 \%$ \\
\hline 16 & Keberadaan nurshery habitat $(\mathrm{KNH})$ & $100 \%$ \\
\hline 17 & Keberadaan spawning ground (KSG) & $100 \%$ \\
\hline 18 & Rentang Pasang surut (RPS) & $90 \%$ \\
\hline 19 & Jenis Substrat (JSb) & $90 \%$ \\
\hline 20 & Jenis flora mangrove $(\mathrm{JMg})$ & $90 \%$ \\
\hline 21 & $\begin{array}{l}\text { Perbandingan kerapatan anakan dan } \\
\text { pohon mangrove (PAP) }\end{array}$ & $90 \%$ \\
\hline 22 & Jenis fauna mangrove (JFM) & $90 \%$ \\
\hline 23 & Ruang hidup fauna mangrove (RFM) & $90 \%$ \\
\hline 24 & $\begin{array}{l}\text { Kemampuan gerak fauna mangrove } \\
\text { (GFM) }\end{array}$ & $90 \%$ \\
\hline 25 & $\begin{array}{l}\text { Status perlindungan ekosistem mangrove } \\
\text { (SLM) }\end{array}$ & $90 \%$ \\
\hline 26 & Kondisi ekosistem mangrove (KEM) & $80 \%$ \\
\hline
\end{tabular}

\section{Kemampuan variabel mewakili karakteristik ekosistem mangrove}

Dua puluh enam variabel IKE ekosistem mangrove tersebut menggambarkan karakteristik ekosistem mangrove yang kompleks. Kompleksitas ekosistem digambarkan adanya variabel yang terkait dengan unsur lingkungan, flora, fauna dan ekosistem (Gambar 2). Kompleksitas variabel lebih detail dapat dirinci dengan memperhatikan karakteristik yang lebih spesisifik dan keterkaitan variabel dengan kondisi ekosistem mangrove apabila terkena tumpahan minyak. Kompleksitas detail variabel-variabel tersebut meliputi karakteristik lingkungan, karakteristik flora, karakteristik vegetasi, karakteristik nilai dan fungsi ekologi, karakteristik fauna, dan karakteristik perlindungan. Beragamnya karakteristik yang ada dalam variabel-variabel tersebut menggambarkan variabel-veriabel IKE ekosistem mangrove terpilih akan mampu mewakili karakteristik ekosistem mangrove, sehingga indeks yang terbentuk akan memberikan nilai yang akurat dalam menentukan tingkat kepekaan ekologi suatu ekosistem mangrove terhadap tumpahan minyak. 


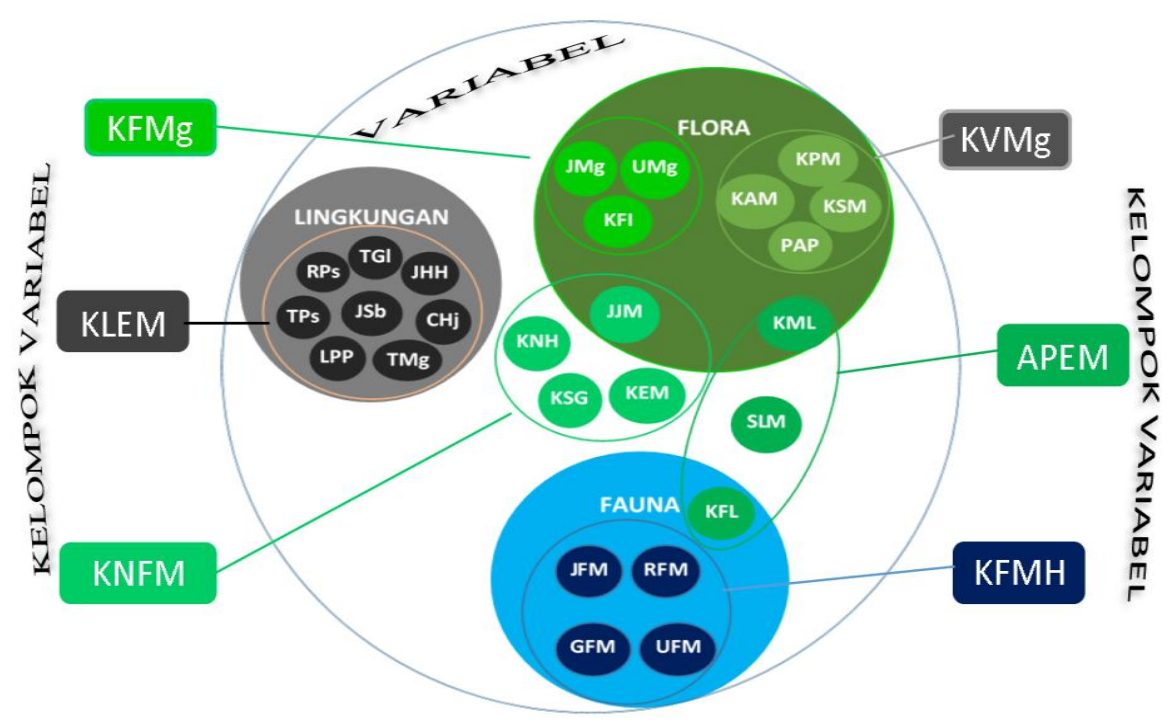

Gambar 2. Variabel dan Kelompok variabel IKE ekosistem mangrove.

Figure 2. Variables and Variable Groups of mangrove ecositems ESI.

Berdasarkan kompleksitas karakteristik ekosistem yang dimiliki oleh variabel, maka variabel-variabel IKE ekosistem mangrove dapat dikelompokkan menjadi 6 kelompok. Enam kelompok variabel tersebut adalah karakteristik lingkungan ekosistem mangrove (KLEM), karakteristik flora mangrove
(KFMg), karakteristik vegetasi mangrove $(\mathrm{KVMg})$, karakteristik nilai dan fungsi ekosistem mangrove (KNFM), karakteristik fauna mangrove dan habitatnya (KFMH), serta aspek perlindungan ekosistem mangrove (APEM) (Tabel 4).

Tabel 4. Pengelompokkan variabel-variabel IKE ekosistem mangrove

Table 4. Clustering of variables of mangrove ecosistems ESI

\begin{tabular}{|c|c|c|c|}
\hline No & $\begin{array}{c}\text { Kelompok } \\
\text { Variabel }\end{array}$ & Karakteristik Kelompok Variabel & Variabel \\
\hline 1 & $\begin{array}{l}\text { Kondisi Lingkungan } \\
\text { Ekosistem } \\
\text { Mangrove (KLEM) }\end{array}$ & $\begin{array}{l}\text { - menggambarkan kondisi lingkungan berupa } \\
\text { aspek oseanografi, iklim, lingkungan fisik, dan } \\
\text { posisi ekosistem mangrove } \\
\text { - kondisi lingkungan ekosistem mangrove akan } \\
\text { mempengaruhi minyak mudah atau sulit } \\
\text { tercuci secara alami }\end{array}$ & $\begin{array}{l}\text { a.Tipe pasang surut (TPS) } \\
\text { b. Rentang pasang surut (RPS) } \\
\text { c. Tinggi gelombang (TGl) } \\
\text { d. Curah hujan }(\mathrm{CHj}) \\
\text { e. Jumlah hari hujan (JHH) } \\
\text { f. Jenis substrat (JSb) } \\
\text { g.Lama penggenangan pasang (LPP) } \\
\text { h. Tipologi mangrove (TMg) }\end{array}$ \\
\hline 2 & $\begin{array}{l}\text { Karakteristik Flora } \\
\text { Mangrove (KFMg) }\end{array}$ & $\begin{array}{l}\text { - berkaitan dengan jenis, umur, dan sifat invasif } \\
\text { flora } \\
\text { - tumpahan minyak akan menyebabkan } \\
\text { gangguan fisik sampai kematian flora } \\
\text { mangrove }\end{array}$ & $\begin{array}{l}\text { a. Jenis flora mangrove }(\mathrm{JMg}) \\
\text { b. Umur flora mangrove }(\mathrm{UMg}) \\
\text { c. Keberadaan flora invansif }(\mathrm{KFI})\end{array}$ \\
\hline 3 & $\begin{array}{l}\text { Karakteristik } \\
\text { Vegetasi Mangrove } \\
\text { (KVMg) }\end{array}$ & $\begin{array}{l}\text { - menggambarkan karakteristik vegetasi } \\
\text { mangrove } \\
\text { - mempengaruhi kemudahan/kesulitan dalam } \\
\text { membersihkan minyak di ekosistem mangrove }\end{array}$ & $\begin{array}{l}\text { a. Kerapatan pohon mangrove (KPM) } \\
\text { b. Kerapatan anakan mangrove (KAM) } \\
\text { c. Kerapatan semai mangrove (KSM) } \\
\text { d. Perbandingan kerapatan anakan dan pohon } \\
\quad \text { mangrove (PAP) }\end{array}$ \\
\hline 4 & $\begin{array}{l}\text { Karakteristik Fauna } \\
\text { Mangrove dan } \\
\text { Habitatnya (KFMH) }\end{array}$ & $\begin{array}{l}\text { - berkaitan dengan karakteristik fauna dan } \\
\text { habitatnya } \\
\text { - berkaitan dengan tingkat gangguan minyak } \\
\text { terhadap fauna mangrove }\end{array}$ & $\begin{array}{l}\text { a. Jenis fauna mangrove (JFM) } \\
\text { b. Ruang hidup fauna mangrove (RFM) } \\
\text { c. Kemampuan gerak fauna mangrove (GFM) } \\
\text { d. Umur fauna mangrove (UFM) }\end{array}$ \\
\hline 5 & $\begin{array}{l}\text { Karakteristik Nilai } \\
\text { dan Fungsi Ekologi } \\
\text { (KNFM) }\end{array}$ & $\begin{array}{l}\text { - menggambarkan kualitas ekosistem mangrove } \\
\text { berupa keragaman jenis, kondisi ekosistem } \\
\text { mangrove, dan fungsi ekologis mangrove } \\
\text { - kualitas lingkungan mangrove menurun apabila } \\
\text { terkena tumpahan minyak }\end{array}$ & $\begin{array}{l}\text { a. Jumlah Jenis flora mangrove (JJM) } \\
\text { b. Kondisi ekosistem mangrove (KEM) } \\
\text { c. Keberadaan nurshery habitat }(\mathrm{KNH}) \\
\text { d. Keberadaan Spawning ground (KSG) }\end{array}$ \\
\hline 6 & $\begin{array}{l}\text { Aspek Perlindungan } \\
\text { Ekosistem } \\
\text { Mangrove (APEM) }\end{array}$ & $\begin{array}{l}\text { - menggambarkan keberadaan perlindungan } \\
\text { biota dan ekosistem mangrove } \\
\text { - pencemaran minyak akan berdampak pada } \\
\text { kualitas perlindungan }\end{array}$ & $\begin{array}{l}\text { a. Keberadaan flora mangrove yang dilindungi } \\
\text { (KML) } \\
\text { b. Keberadaan fauna mangrove yang dilindungi } \\
\text { (KFL) } \\
\text { c. Status perlindungan ekosistem mangrove } \\
\text { (SLM) }\end{array}$ \\
\hline
\end{tabular}




\section{Rangking Kepekaan Variabel IKE Ekosistem Mangrove}

Rangking kepekaan variabel Indeks kepekaan ekologi (IKE) ekosistem mangrove menunjukkan tingkatan nilai penting setiap variabel dalam menentukan kepekaan ekosistem mangrove secara ekologi terhadap tumpahan minyak. Nilai tersebut diperoleh dari pendapat para pakar dalam menetapkan urutan rangking variabel-variabel IKE ekosistem mangrove. Tabel 5 menyajikan rataan nilai rangking variabel-variabel IKE ekosistem mangrove. Semakin tinggi rataan nilai rangking menunjukkan semakin tinggi rangking variabel tersebut atau semakin penting variabel tersebut dalam menentukan kepekaan ekosistem mangrove secara ekologi terhadap tumpahan minyak.

Berdasarkan rataan nilai rangking pada Tabel 5, variabel-variabel indeks kepekaan ekologi (IKE) ekosistem mangrove terhadap tumpahan minyak dapat dikelompokkan menjadi 5 kelas.

Kelima kelas tersebut adalah sebagai berikut:

1 Kelompok variabel dengan rataan nilai rangking lebih besar dari 20, yaitu terdiri atas variabel keberadaan nurshery habitat, keberadaan spawning ground, tipologi mangrove, dan umur flora mangrove.

2 Kelompok variabel dengan rataan nilai rangking antara 17,5 sampai 20 , yaitu terdiri atas variabel kerapatan semai mangrove, lama waktu penggenangan air pasang, keberadaan flora mangrove yang dilindungi, tipe pasang surut, rentang pasang surut, kerapatan anakan mangrove, umur fauna mangrove, dan status perlindungan ekosistem mangrove.

3 Kelompok variabel dengan rataan nilai rangking antara 15 sampai 17,5 , yaitu terdiri atas variabel curah hujan, keberadaan fauna mangrove yang dilindungi, kerapatan pohon mangrove, jumlah jenis flora mangrove, kondisi ekosistem mangrove, tinggi gelombang, kemampuan gerak fauna mangrove, dan jumlah hari hujan.

4 Kelompok variabel dengan rataan nilai rangking antara 12,5 sampai 15, yaitu variabel perbandingan kerapatan anakan dengan kerapatan pohon mangrove

5 Kelompok variabel dengan rataan nilai rangking antara 10 sampai 12,5 , yaitu variabel keberadaan flora invasif.

Variabel keberadaan nurshery habitat, keberadaan spawning ground, tipologi mangrove, dan umur flora mangrove merupakan variabel-variabel yang tergolong kedalam kelompok rangking sangat tinggi (kelompok variabel dengan rataan nilai rangking lebih besar dari 20). Keempat variabel tersebut juga mendapat persetujuan seluruh pakar $(100 \%)$ sebagai variabel IKE ekosistem mangrove (Tabel 2). Hal ini

Tabel 5. Rataan nilai rangking variabel-variabel IKE ekosistem mangrove

Table 5. Average of variable ranking scores $s$ of mangrove ecosistems ESI

\begin{tabular}{|c|c|c|c|c|c|}
\hline No & Variabel & $\begin{array}{c}\text { Rataan } \\
\text { Nilai } \\
\text { Rangking } \\
\end{array}$ & No & Variabel & $\begin{array}{l}\text { Rataan Nilai } \\
\text { Rangking }\end{array}$ \\
\hline 1 & Keberadaan nurshery habitat & 22,70 & 14 & Keberadaan fauna mangrove yang dilindungi & 17,10 \\
\hline 2 & Keberadaan Spawning ground & 20,70 & 15 & Jenis fauna mangrove & 17,00 \\
\hline 3 & Tipologi mangrove & 20,10 & 16 & Ruang hidup fauna mangrove & 16,90 \\
\hline 4 & Umur flora mangrove & 20,10 & 17 & Jenis flora mangrove & 16,70 \\
\hline 5 & Lama waktu penggenangan air pasang & 19,80 & 18 & Jenis Substrat & 16,60 \\
\hline 6 & Tipe Pasang surut & 19,80 & 19 & Tinggi Gelombang & 16,30 \\
\hline 7 & $\begin{array}{l}\text { Keberadaan flora mangrove yang } \\
\text { dilindungi }\end{array}$ & 19,70 & 20 & Jumlah jenis flora mangrove & 16,00 \\
\hline 8 & Rentang Pasang surut & 19,50 & 21 & Jumlah hari hujan & 15,70 \\
\hline 9 & Kerapatan semai mangrove & 19,30 & 22 & Kerapatan pohon mangrove & 15,50 \\
\hline 10 & Status perlindungan ekosistem mangrove & 18,60 & 23 & Kondisi ekosistem mangrove & 15,50 \\
\hline 11 & Umur fauna mangrove & 18,40 & 24 & Kemampuan gerak fauna mangrove & 15,00 \\
\hline 12 & Kerapatan anakan mangrove & 17,80 & 25 & $\begin{array}{l}\text { Perbandingan kerapatan anakan dan pohon } \\
\text { mangrove }\end{array}$ & 14,50 \\
\hline 13 & Curah hujan & 17,40 & 26 & Keberadaan flora invasif & 10,10 \\
\hline
\end{tabular}

Pengembangan Variabel-Variabel Indeks Kepekaan Ekologi (IKE) Bagi Pengendalian Tumpahan Minyak Di Ekosistem Mangrove - Muarif, Ario, Damar, Sigid Hariyadi, Dewayani Sutrisno, Mennofatria Boer 
menggambarkan status keempat variabel tersebut sangat penting dalam menentukan kepekaan ekosistem mangrove secara ekologi terhadap tumpahan minyak.

Peranan keempat variabel tersebut dalam menentukan kepekaan ekosistem mangrove terhadap tumpahan minyak dapat dijelaskan sebagai berikut:

- Variabel keberadaan nurshery habitat, keberadaan spawning ground merupakan variabel yang yang menggambarkan fungsi ekologi mangrove yang sangat penting bagi keberlanjutan sumberdaya hayati di kawasan pesisir. Peters et al. (1997) menjelaskan hutan bakau sebagai habitat berbagai jenis organisme, maka kerusakannya juga akan membahayakan biota yang bergantung pada mangrove, sebagai akibat rusaknya spawining ground dan nurshery habitat.

- Umur tanaman akan mempengaruhi kepekaan mangrove terhadap minyak (Lin dan Mendelssohn, 1998). Hoff et al. (2002) melaporkan bibit dan anakan, lebih rentan terhadap paparan minyak. Menurut Getter dan Ballou (1985), anakan mangrove juga lebih peka dibandingkan pohon karena penyerapan hidrokarbon minyak bumi tinggi pada bibit dan rendah pada pohon dewasa.

- Tipologi mangrove menggambarkan karakter yang unik terhadap tumpahan minyak. Pengamatan IPIECA (1993) pada kejadian tumpahan minyak di Selat Malaka mendapatkan ekosistem mangrove dengan tipologi mangrove tepi memiliki kerentanan yang tinggi terhadap tumpahan minyak, akan tetapi secara alami kepekaannya rendah (mangrove mampu bertahan hidup) karena minyak mudah tercuci oleh gelombang dan pasut. Sebaliknya pada ekosistem mangrove dibelakangnya ditemukan kematian mangrove yang tinggi.

Tabel 6 Karakteristik variabel-variabel IKE ekosistem mangrove di Indramayu Table 6. Characteristics of variables of mangrove ecosistems ESI in Indramayu

\begin{tabular}{|c|c|c|c|c|c|c|}
\hline \multirow{2}{*}{ Variabel } & \multicolumn{6}{|c|}{ Karakteristik Variabel } \\
\hline & Stasiun 1 & Stasiun 2 & Stasiun 3 & Stasiun 4 & Stasiun 5 & Stasiun 6 \\
\hline TPs & $\begin{array}{c}\text { Campuran } \\
\text { condong tunggal }\end{array}$ & $\begin{array}{c}\text { Campuran } \\
\text { condong tunggal }\end{array}$ & $\begin{array}{c}\text { Campuran } \\
\text { condong tunggal }\end{array}$ & $\begin{array}{c}\text { Campuran } \\
\text { condong tunggal }\end{array}$ & $\begin{array}{c}\text { Campuran } \\
\text { condong tunggal }\end{array}$ & $\begin{array}{c}\text { Campuran } \\
\text { condong tunggal }\end{array}$ \\
\hline RPs & $2,37 \mathrm{~m}$ & $2,37 \mathrm{~m}$ & $2,37 \mathrm{~m}$ & $2,37 \mathrm{~m}$ & $2,37 \mathrm{~m}$ & $2,37 \mathrm{~m}$ \\
\hline TGl & $<0,5$ & $<0,5$ & $<0,5$ & $<0,5$ & $<0,5$ & $<0,5$ \\
\hline $\mathrm{CHj}$ & 1.428 & 1.428 & 1.428 & 1.359 & 1.359 & 1.359 \\
\hline $\mathrm{JHH}$ & 148 & 148 & 148 & 162 & 162 & 162 \\
\hline $\mathrm{JSb}$ & Lumpur berpasir & Lumpur berpasir & Lumpur berpasir & Lumpur berpasir & Lumpur berpasir & Lumpur \\
\hline LPP & 15 hari & 15 hari & 15 hari & 7 hari & 7 hari & 15 hari \\
\hline $\mathrm{TMg}$ & $\begin{array}{l}\text { Riverine } \\
\text { mangrove }\end{array}$ & Fringe mangrove & Fringe mangrove & $\begin{array}{l}\text { Riverine } \\
\text { mangrove }\end{array}$ & $\begin{array}{l}\text { Riverine } \\
\text { mangrove }\end{array}$ & Fringe mangrove \\
\hline $\mathrm{JMg}$ & Rhizophora & Avicennia & Rhizophora & Rhizophora & Rhizophora & Rhizophora \\
\hline $\mathrm{UMg}$ & Pohon & $\begin{array}{c}\text { Semai, Anakan, } \\
\text { Pohon }\end{array}$ & $\begin{array}{c}\text { Semai, Anakan, } \\
\text { Pohon }\end{array}$ & $\begin{array}{c}\text { Semai, Anakan, } \\
\text { Pohon }\end{array}$ & $\begin{array}{c}\text { Semai, Anakan, } \\
\text { Pohon }\end{array}$ & $\begin{array}{c}\text { Semai, Anakan, } \\
\text { Pohon }\end{array}$ \\
\hline KFI & Tidak ada & Tidak ada & Tidak ada & Tidak ada & Tidak ada & Tidak ada \\
\hline KPM & $5.600 \mathrm{idv} / \mathrm{Ha}$ & $1.633 \mathrm{idv} / \mathrm{Ha}$ & $1.300 \mathrm{idv} / \mathrm{Ha}$ & $2.000 \mathrm{idv} / \mathrm{Ha}$ & $3.033 \mathrm{idv} / \mathrm{Ha}$ & $1.967 \mathrm{idv} / \mathrm{Ha}$ \\
\hline KAM & 0 & $7.600 \mathrm{idv} / \mathrm{Ha}$ & $3.333 \mathrm{idv} / \mathrm{Ha}$ & $5.867 \mathrm{idv} / \mathrm{Ha}$ & $5.200 \mathrm{idv} / \mathrm{Ha}$ & $2.667 \mathrm{idv} / \mathrm{Ha}$ \\
\hline KSM & 0 & $53.333 \mathrm{idv} / \mathrm{Ha}$ & $116.667 \mathrm{idv} / \mathrm{Ha}$ & $220.000 \mathrm{idv} / \mathrm{Ha}$ & $82.000 \mathrm{idv} / \mathrm{Ha}$ & $110.000 \mathrm{idv} / \mathrm{Ha}$ \\
\hline PAP & 0 & 4,65 & 2,56 & 2,93 & 1,71 & 1,36 \\
\hline JFM & $\begin{array}{c}\text { Gastropoda, } \\
\text { kepiting, udang, } \\
\text { ikan, } \\
\text { biawak,burung }\end{array}$ & $\begin{array}{c}\text { Gastropoda, } \\
\text { kepiting, udang, } \\
\text { ikan, } \\
\text { biawak,burun. }\end{array}$ & $\begin{array}{c}\text { Gastropoda, } \\
\text { kepiting, udang, } \\
\text { ikan, } \\
\text { biawak,burun. }\end{array}$ & $\begin{array}{c}\text { Gastropoda, } \\
\text { kepiting, udang, } \\
\text { ikan, } \\
\text { biawak,burung }\end{array}$ & $\begin{array}{c}\text { Gastropoda, } \\
\text { kepiting, udang, } \\
\text { ikan, } \\
\text { biawak,burung }\end{array}$ & $\begin{array}{c}\text { Gastropoda, } \\
\text { kepiting, udang, } \\
\text { ikan, } \\
\text { biawak,burung }\end{array}$ \\
\hline RFM & $\begin{array}{c}\text { Substrat, air, akar, } \\
\text { batang, kanopi }\end{array}$ & $\begin{array}{c}\text { Substrat, air, akar, } \\
\text { batang, kanopi }\end{array}$ & $\begin{array}{l}\text { Substrat, air, akar, } \\
\text { batang, kanopi }\end{array}$ & $\begin{array}{c}\text { Substrat, air, akar, } \\
\text { batang, kanopi }\end{array}$ & $\begin{array}{c}\text { Substrat, air, akar, } \\
\text { batang, kanopi }\end{array}$ & $\begin{array}{l}\text { Substrat, air, akar, } \\
\text { batang, kanopi }\end{array}$ \\
\hline GFM & $\begin{array}{l}\text { Sangat lambat- } \\
\text { sangat cepat }\end{array}$ & $\begin{array}{l}\text { Sangat lambat- } \\
\text { sangat cepat }\end{array}$ & $\begin{array}{c}\text { Sangat lambat- } \\
\text { sangat cepat }\end{array}$ & $\begin{array}{l}\text { Sangat lambat- } \\
\text { sangat cepat }\end{array}$ & $\begin{array}{c}\text { Sangat lambat- } \\
\text { sangat cepat }\end{array}$ & $\begin{array}{c}\text { Sangat lambat- } \\
\text { sangat cepat }\end{array}$ \\
\hline UFM & Jurvenil, dewasa & Jurvenil, dewasa & Jurvenil, dewasa & Jurvenil, dewasa & Jurvenil, dewasa & Jurvenil, dewasa \\
\hline JJM & 2 & 2 & 2 & 4 & 4 & 2 \\
\hline KEM & Sangat baik & Sangat baik & Baik & Sangat baik & Sangat baik & Sangat baik \\
\hline $\mathrm{KNH}$ & Ada & Ada & Ada & Ada & Ada & Ada \\
\hline KSG & Ada & Ada & Ada & Ada & Ada & Ada \\
\hline KML & Tidak ada & Tidak ada & Tidak ada & Tidak ada & Tidak ada & Tidak ada \\
\hline KFL & Ada & Ada & Ada & Ada & Ada & Ada \\
\hline SLM & Non konservasi & Non konservasi & Non konservasi & Non konservasi & Non konservasi & Non konservasi \\
\hline
\end{tabular}


Flora invasif sebagai salah satu variabel IKE ekosistem mangrove disetujui oleh seluruh pakar $(100 \%)$, akan tetapi para pakar menilai keberadaan flora invasif peranannya kecil dalam mempengaruhi kepekaan ekosistem mangrove (termasuk ke dalam kelompok variabel dengan rataan nilai rangking antara 10 sampai 12,5). Dengan demikian gangguan dari luar seperti flora invasif dinilai tidak berdampak penting pada kepekaan mangrove terhadap tumpahan minyak, sebaliknya faktor internal yang dinilai paling berperan seperti keberadaan nurshery habitat, tipologi mangrove, umur flora mangrove, dan keberadaan spawning ground.

\section{Uji Coba Variabel bagi Penilaian Kepekaan Ekologi Mangrove di Pesisir Indramayu}

Secara umum ekosistem mangrove di setiap stasiun penelitian memiliki sebagian besar karakteristik yang relatif seragam. Hal ini ditunjukkan oleh keberadaan 14 variabel yang memiliki karakteristik yang sama di setiap stasiun. Variabel-variabel yang memiliki nilai sama di setiap stasiun meliputi tipe pasang surut, rentang pasang surut, tinggi gelombang, jenis substrat, tipologi mangrove, keberadaan flora invasif, jenis fauna mangrove, ruang hidup fauna mangrove, kemampuan gerak fauna mangrove, umur fauna, keberadaan nurshery habitat, keberadaan spawning ground, keberadaan flora mangrove dilindungi, keberadaan fauna dilindungi, dan status perlindungan ekosistem mangrove (Tabel 6). Faktor pembeda antar stasiun terdapat pada 12 variabel yaitu lama penggenangan pasang (LPP), curah hujan $(\mathrm{CHj})$, jumlah hari hujan (JHH), jenis flora mangrove ( $\mathrm{JMg})$, umur flora mangrove (UMg), kerapatan pohon mangrove (KPM), kerapatan anakan mangrove (KAM), kerapatan semai mangrove (KSM), perbandingan anakan dan pohon (PAP), tipologi mangrove (TMg), jumlah jenis mangrove (JJM), dan kondisi ekosistem mangrove (KEM).
Tabel 7 menyajikan nilai kepekaan ekologi mangrove di pesisir Kabupaten Indramayu. Setiap variabel memiliki nilai kepekaan yang berkisar mulai 1 (tidak peka) sampai 5 (sangat peka). Variabel yang memiliki tingkat kepekaan tertinggi di setiap stasiun adalah tinggi gelombang (TGl), keberadaan nurshery habitat $(\mathrm{KNH})$, spawining ground (KSG), dan fauna yang dilindungi (KFL). Enam stasiun penelitian memiliki gelombang yang rendah yang akan sulit mencuci minyak (Adeofun, 2011), sehingga kepekaan ekosistem mangrove menjadi tinggi. Seluruh stasiun memiliki spawning ground dan nurshery habitat, sehingga tergolong memiliki kepekaan yang tinggi (Peters et al., 1997). Keberadaan fauna yang dilindungi terlihat dari keberadaan burung-burung dilindungi yang hidup di dalam atau di sekitar ekosistem mangrove. Jenis-jenis burung dilindungi yang berada di pesisir Kabupaten Indramayu antara lain kuntul, cangak, camar, dan raja udang. Fauna yang dilindungi keberadaannya penting untuk dipertahankan, sehingga tergolong sangat peka apabila terkena tumpahan minyak (NOOA, 2002).

Nilai kepekaan terendah dimiliki variabel jumlah hari hujan $(\mathrm{JHH})$, keberadaan flora invasif (KFI), keberadaan flora mangrove yang dilindungi (KML), dan status lindung mangrove (SLM). Jumlah hari hujan berkisar antara 148-162 hari pertahun. Kisaran jumlah hari hujan tersebut masuk kedalam katagori sangat besar (BMKG, 2013). Jumlah hari hujan yang besar menggambarkan kemampuan hujan dalam mencuci minyak, yaitu semakin besar jumlah hari hujan akan semakin besar pula kemampuannya dalam mencuci minyak, sehingga nilai kepekaannya tergolong sangat rendah. Hasil pengamatan dan penelusuran data sekunder pada 6 stasiun tidak ditemukan keberadaan flora mangrove invasif (KFI), flora mangrove dilindungi (KML), dan status lindung mangrove (SLM) sehingga tiga variabel ini memiliki nilai kepekaan yang sangat rendah (NOOA, 2002; dan IPIECA, 2012). 
Tabel 7. Nilai kepekaan ekologi mangrove di Indramayu

Table 7. Score of ecological sensitivity of mangrove in Indramayu

\begin{tabular}{|c|c|c|c|c|c|c|}
\hline \multirow{2}{*}{ Variabel } & \multicolumn{6}{|c|}{ Nilai Kepekaan } \\
\hline & St 1 & St 2 & St 3 & St 4 & St 5 & St 6 \\
\hline TPs & 4 & 4 & 4 & 4 & 4 & 4 \\
\hline RPs & 3 & 3 & 3 & 3 & 3 & 3 \\
\hline TGl & 5 & 5 & 5 & 5 & 5 & 5 \\
\hline $\mathrm{CHj}$ & 4 & 4 & 4 & 4 & 4 & 4 \\
\hline JHH & 1 & 1 & 1 & 1 & 1 & 1 \\
\hline $\mathrm{JSb}$ & 4 & 4 & 4 & 4 & 4 & 4 \\
\hline LPP & 3 & 3 & 3 & 4 & 4 & 3 \\
\hline $\mathrm{TMg}$ & 3 & 3 & 3 & 3 & 3 & 3 \\
\hline $\mathrm{JMg}$ & 4 & 5 & 4 & 4 & 4 & 4 \\
\hline UMg & 2 & 3 & 3 & 3 & 3 & 3 \\
\hline KFI & 1 & 1 & 1 & 1 & 1 & 1 \\
\hline KPM & 5 & 5 & 4 & 5 & 5 & 5 \\
\hline KAM & 1 & 5 & 5 & 5 & 5 & 5 \\
\hline
\end{tabular}

\begin{tabular}{lcccccc}
\hline \multirow{2}{*}{ Variabel } & \multicolumn{7}{c}{ Nilai Kepekaan } \\
\cline { 2 - 6 } & St 1 & St 2 & St 3 & St 4 & St 5 & St 6 \\
\hline KSM & 1 & 5 & 5 & 5 & 5 & 5 \\
PAP & 1 & 5 & 3 & 3 & 2 & 1 \\
JFM & 3 & 3 & 3 & 3 & 3 & 3 \\
RFM & 3 & 3 & 3 & 3 & 3 & 3 \\
GFM & 3 & 3 & 3 & 3 & 3 & 3 \\
UFM & 3 & 3 & 3 & 3 & 3 & 3 \\
JJM & 4 & 4 & 4 & 5 & 5 & 4 \\
KEM & 5 & 5 & 4 & 5 & 5 & 5 \\
KNH & 5 & 5 & 5 & 5 & 5 & 5 \\
KSG & 5 & 5 & 5 & 5 & 5 & 5 \\
KML & 1 & 1 & 1 & 1 & 1 & 1 \\
KFL & 5 & 5 & 5 & 5 & 5 & 5 \\
SLM & 1 & 1 & 1 & 1 & 1 & 1 \\
\hline Nilai IKE & 2,99 & 3,72 & 3,49 & 3,63 & 3,59 & 3,50 \\
\hline IKE & CP & P & P & P & P & P \\
\hline
\end{tabular}

Indeks kepekaan ekologi (IKE) ekosistem mangrove di Kabupaten Indramayu menunjukkan stasiun 1 tergolong cukup peka, sedang stasiun 2, stasiun3, stasiun 4, stasiun 5, dan stasiun 6 tegolong peka. Hasil uji Friedman menunjukkan bahwa karakteristik antar stasiun berbeda nyata $(\mathrm{P}<0,05)$. Hasil uji lanjut menggunakan uji Wilcoxon menunjukkan stasiun 1 berbeda nyata dengan stasiun 2, stasiun 4, dan stasiun 5. Faktor yang membedakan stasiun 1 dengan 5 stasiun lainnya adalah umur mangrove ( $\mathrm{UMg})$, kerapatan anakan mangrove (KAM), kerapatan semai mangrove (KSM), dan perbandingan anakan dan pohon (PAP)

\section{KESIMPULAN DAN SARAN}

Pada penelitian teridentifikasi sebanyak 26 variabel terpilih layak menjadi variabel indeks kepekaan ekologi (IKE) ekosistem mangrove terhadap tumpahan minyak, karena secara ilmiah valid dan mendapat persetujuan pakar internasional. Variabel-variabel tersebut mampu mewakili kompleksitas karakteristik ekosistem mangrove, hal itu tergambar dari 6 karakteristik ekosistem mangrove yang tercermin dalam 6 kelompok variabel. Variabel nurshery habitat, keberadaan spawning ground, tipologi mangrove, dan umur flora mangrove merupakan variabel yang memiliki nilai rangking tertinggi, sedangkan variabel keberadaan flora invasif adalah variabel yang memiliki nilai rangking terendah. Sebaran indeks kepekaan ekologi (IKE)

ekosistem mangrove di pesisir Kabupaten Indramayu meliputi cukup peka sampai peka, dengan sebagian besar stasiun memiliki indeks kepekaan yang tergolong peka.

\section{UCAPAN TERIMA KASIH}

Ucapan terima kasih disampaikan kepada Prof. DG Bengen, Prof. C Kusmana, Dr. N Santoso (IPB, Indonesia), Dr.RA Feagin (Texas A\&M University), Prof JC Wasserman (UFF, Brazil), P. Vermeiren, PhD (James Cook University, Australia), Dr. L Schwendenmann (University of Auckland, New Zealand), Prof. K Kathiresan (Annamalai University, India), Dr. S Arockiaraj (ICMAM-PD, India) dan Prof LP Jayatissa (University of Ruhuna, Sri Langka) atas kerjasama dan partisipasinya dalam pengisian kuisioner penelitian ini.

\section{DAFTAR PUSTAKA}

Ali, H., Poerbandono, dan K. Wikantika. 2008. Penentuan indeks kerentanan lingkungan pantai berbasis geospasial dan parameter fisik (studi kasus : tumpahan minyak di Kepulauan Seribu, Teluk Jakarta). PIT MAPIN XVII, Bandung 10-12-2008. 196207.

Brown, B. 2007. Resilience thinking applied to the mangroves of Indonesia. Yogyakarta (ID): IUCN \& Mangrove Action Project. 52 p.

Burnsa, K.A., S. Codia, C. Pratta, dan N.C. Dukeb. 1999. Weathering of hydrocarbons in mangrove sediments: testing the effects of using dispersants to treat oil spills. $J$. 
Organic Geochemistry 30 (1999) 12731286 .

Clark, R.B. 1986. Marine pollution. Oxford (UK): Oxford University Press, Oxford, UK. 1986. $215 \mathrm{p}$.

Clayton, M. J. 1997. Delphi: A technique to harness expert opinion for critical decisionmaking tasks in education. Educational Psychology, 17(4), 373-384.

Cooke, R.M. dan L.H.J. Goossens. 2000. Procedures guide for structured expert judgement in accident consequence modelling. Radiation Protection Dosimetry vol. 90, No.3 303-309.

Crance, J.H. 1987. Guidelines for using the delphi technique to develop habitat suitability index curves Biological Report 82 (10.134). National Ecology Center a Division of Wildlife and Contaminant Research Fish and Wildlife Service U.S. Department of the Interior Washington, DC. $30 \mathrm{p}$.

Culbertson, J., I.Valiela, E.Peacock, C.Reddy, A. Carter, dan R. Vander Kruik. 2007. Longterm effects of petroleum residues on fiddler crabs in salt marshes. Marine Pollution Bulletin 54, 955-962.

De Lange, H.J., J. Lahr, J.J.C. Van Der Pol, Y. Wessels, dan J.H. Faber. 2009. Ecological vulnerability in wildlife: an expert judgment and multicriteria analysis tool using ecological traits to assess relative impact of pollutants. Environmental Toxicology and Chemistry, Vol. 28, No. 10, Pp. 2233-2240.

Donnelly, A., M. Jones, T. O'Mahony, dan G. Byrne. 2007. Selecting environmental indicator for use in strategic environmental assessment. Environmen-tal Impact Assessment Review 27 (2007): 161-175.

Duke, N.C. dan K.A. Burn. 1999. Fate and effects of oil and dispersed oil on mangrove ecosystems in Australia. Australian (AU): Australian Institute of Marine Science and CRC Reef Research Centre. 233-247.

Emerson. 1983. Oil Effects On Terrestrial Plants And Soils: A Review. Ontario Ministry of the Environment. Ontario.

Fazey, I., J.A. Fazey, dan D.M.A. Fazey. 2005. Learning more effectively from experience. Ecology and Society, 10, 4.

Faperikan IPB. 1995. Studi Pemetaan Indeks Kepekaan Lingkungan Wilayah Pesisir Indramayu dan Subang Jawa Barat Berkaitan dengan Dampak Kegiatan Pertamina. Bogor (ID): Kejasama Pertamina dengan Fakultas Perikanan IPB.

Fazey, I., K. Proust, B. Newell, B. Johnson, dan J. A. Fazey. 2006. Eliciting the implicit knowledge and perceptions of on-ground conservation managers of the Macquarie Marshes. Ecology and Society 11(1): 25.
Fingas, M. 2001. The Basic of oil spill cleanup. 2nd ed. Washington DC (US): Lewis Publishers. 230p.

Garrity, S.D.; S.C. Levings dan K.A. Burns. 1994. The Galeta Oil Spill. Long-term Effects onthe Physical Structure of the Mangrove Fringe. Estuarine, Coastal and Shelf Science. 1994, 38:4, Florida. P: 327-348.

Getter, C.D. dan T.G. Ballou. 1985. Field experiments on the effects of oil and dispersant on mangroves. International Oil Spill Conference Proceedings: February 1985, Vol. 1985, No. 1, pp. 577-582.

Hilty, J. dan A. Merenlender. 2000. Faunal indicator taxa selection for monitoring ecosystem health. Biological Conservation $92: 185-197$

Hoff, R., P. Hensel, E.C. Proffitt, P. Delgado, G. Shigenaka, dan R. Yender. 2002. Oil spill in mangrove, planning and response considerations. Washington (US): NOAA Ocean Service, Office of Response and Restoration. 70p.

[IPIECA] International Petroleum Industry Environmental Conservation Association. 1993. Biological impacts of oil pollution: mangroves. IPIECA Report Series Volume Four. London (UK): International Petroleum Industry Environmental Conservation Association. 20p.

[IPIECA/IMO/OGP] International Petroleum Industry Environmental Conservation Association/International Maritime Organisation/International Association of Oil and Gas Producers. (2012). Sensitivity mapping for oil spill response. London (UK): The Global Oil and Gas Industri Association for Environmental and Social Issues, International Maritime Organization, International Association of Oil \& Gas Producers. 33p.

Kolyuchkina, G.A., N.A. Belyaev, V.A. Spiridonov, dan U.V. Simakova. 2012. Long-term effects of Kerch Strait residual oil-spill: hydrocarbon concentration in bottom sediments and biomarkers in Mytilus galloprovincialis (Lamarck, 1819). Turkish Journal of Fisheries and Aquatic Sciences 12: $461-469$ (2012). Central Fisheries Research Institute (CFRI) Trabzon, Turkey in cooperation with Japan International Cooperation Agency (JICA), Japan.

Lin, Q. dan I.A. Mendelssohn. 1996. A comparative investigation of the effects of south Louisiana crude oil on the vegetation of fresh, brackish and salt marshes. Marine Pollution Bulletin, Volume 32, Issue 2, February 1996, 202-209. 
McBride, M.F., F. Findler, dan M.A. Burgman. 2012. Evaluating the accuracy and calibration of expert predictions under uncertainty: predicting the outcomes of ecological research. Diversity and Distributions, (Diversity Distrib.) (2012) 113.

Melville, F., L.E. Anderson dan D.F. Jolley. 2009. The Gladstone (Australia) oil spill - Impacts on intertidal areas: Baseline and six months post-spill. Marine Pollution Bulletin 58, 263-267.

Messmer, T., R. Drake dan A. McElrone. 1998. Endangered and threatened animals of Utah. Logan (US): Berryman Institute Publication No. 17, Utah State University. $60 \mathrm{pp}$.

Meyer. M.A. dan J.M. Booker. 2001. Eliciting and analizing expert judgment: a practical guide. Philadelphia (US): The American Statistical Association and Society for Industrial and Applied Mathematics. 459 p.

Ministry of Water, Land and Air Protection. 2004. Environmental best management practices for urban and rural land development; environmentally sensitive areas (section five). British Columbia: Ministry of Water, Land and Air Protection. 5-9.

O’Hagan, A., C.E Buck, A. Daneshkhah, J.R. Eiser, P.H. Garthwaite, D.J. Jenkinson, J.E. Oakley, dan T. Rakow. 2006. Uncertain judgements: eliciting experts' probabilities. Hoboken, $\mathrm{NJ}$ : Wiley. xiii+321 pp.

Oldeman, L. R. 1975. The Agroclimatic Map of Java and Madura. Bogor: Contributions from the Central Reseacrh Institute for Agriculture.

O'Sullivan A.J., Jacques T.G. 2001. Impact Reference System - Effects of Oil in the Marine Environment: Impact of Hydrocarbons on Fauna and Flora. European Commission Directorate General Environment Civil Protection and Environmental Accidents Rue de la Loi, 200 - B - 1049 Brussels Belgium.

Oyedepo, J.A. dan C.O. Adeofun. 2011. Environmental sensitivity index mapping of Lagos shorelines. Global NEST Journal, 13 (3), 277-287.

Peters, E.C., N.J. Gassman, J.C. Firman, R.H. Richmond, dan E.A. Power. 1997. Ecotoxicology of tropical marine ecosystems. Environmental Toxicology and Chemistry, 16 (1), 12-40.

Petersen, J., J. Michel, S. Zengel, M. White, C. Lord dan C. Plank. 2002. Environmental sensitivity index guidelines version 3.0.
National Oceanic and Atmospheric Administration (NOOA), U.S. Department of Commerce. Seattle, Washington. 192p.

Souza, P.W.M., F.D. Goncalves, S.W.P. Rodrigues, F.R. Costa dan F.P. Miranda. 2009. Multisensor data fusion for geomorphological and environmental sensitivity index mapping in the Amazonian Mangrove Coast, Brazil. Journal of Coastal Research, SI 56 Proceedings of 10th International Coastal Symposium , 15921596, Lisbon Portugal.

Suharnoto Y. 2000. Environmental Sensitivity Mapping and Database Development: The Case of Indonesia Coastal and Marine Areas. Di dalam: Environmental Workshop on the Environmental Sensitivity Index (ESI) Mapping for Oil Spills, Experiences in Southeast Asian Seas. Tokyo: hlm128-140

Van Loon AF, Dijksma R, dan Van Mensvoort MEF. 2007. Hydrological classification in mangrove areas: A case study in Can Gio, Vietnam. Aquatic Botany 87 (2007) 80-82.

Yousuf, MI. 2007. Using experts' opinions through delphi technique. Practical Assessment, Research \& Evaluation, 12 (4). 